\title{
Response of soil microbial community composition and function to a bottomland forest restoration intensity gradient
}

\author{
Michael S. Strickland ${ }^{\mathrm{a}, \mathrm{b}, *}$, Mac A. Callaham Jr. ${ }^{\mathrm{c}}$, Emile S. Gardiner ${ }^{\mathrm{d}}$, John A. Stanturf ${ }^{\mathrm{c}}$, \\ Jonathan W. Leffe, Noah Fierer ${ }^{\mathrm{e}, \mathrm{f}}$, Mark A. Bradford ${ }^{\mathrm{g}}$ \\ a Department of Biological Sciences, Virginia Tech, Blacksburg, VA 24061, USA \\ b Department of Soil and Water Systems, University of Idaho, Moscow, ID 83844, USA \\ c USDA, Forest Service, Southern Research Station, Center for Forest Disturbance Science, Athens, GA 30602, USA \\ ' USDA, Forest Service, Southern Research Station, Center for Bottomland Hardwoods Research, Stoneville, MS 38776, USA \\ e Department of Ecology and Evolutionary Biology, University of Colorado, Boulder, CO 80309, USA \\ ${ }^{\mathrm{f}}$ Cooperative Institute for Research in Environmental Sciences, University of Colorado, Boulder, CO 80309, USA \\ ${ }^{g}$ School of Forestry and Environmental Studies, Yale University, New Haven, CT 06511, USA
}

\section{A R T I C L E I N F O}

\section{Keyword:}

Hardwood forest

Ecosystem function

Microbial communities

Restoration

Soil processes

Carbon cycling

Plant-soil feedbacks

Aboveground-belowground interactions

\begin{abstract}
A B S T R A C T
Terrestrial ecosystems are globally under threat of loss or degradation. To compensate for the impacts incurred by loss and/or degradation, efforts to restore ecosystems are being undertaken. These efforts often focus on restoring the aboveground plant community with the expectation that the belowground microbial community will follow suit. This 'Field of Dreams' expectation - if you build it, they will come - makes untested assumptions about how microbial communities and their functions will respond to aboveground-focused restoration. To determine if restoration of aboveground plant communities equates to restoration of belowground microbial communities, we assessed the effects of four forest restoration treatments - varying in intensity from unmanaged to interplanting tree species - on microbial (i.e. prokaryotic and fungal) community composition and function (i.e. catabolic profiles and extracellular enzyme activities). Additionally, effects of the restoration treatments were compared to both degraded (i.e. active arable cultivation) and target endpoint communities (i.e. remnant bottomland forest) to determine the trajectory of intensifying aboveground restoration efforts on microbial communities. Approximately 16 years after the initiation of the restoration treatments, prokaryotic and fungal community composition, and microbial function in the four restoration treatments were intermediate to the endpoint communities. Surprisingly, intensification of aboveground restoration efforts led to few differences among the four restoration treatments and increasing intensification did not consistently lead to microbial communities with greater similarity in composition and function to the target remnant forest communities. Together these results suggest that belowground microbial community composition and function will respond little to, or will lag markedly behind, intensifying aboveground restoration efforts. Reliance on a 'Field of Dreams' approach, even if you build it better, may still lead to belowground microbial communities that remain uncoupled from aboveground communities. Importantly, our findings suggest that restoring aboveground vegetation may not lead to the intended restoration of belowground microbial communities and the ecosystem processes they mediate.
\end{abstract}

\section{Introduction}

Terrestrial ecosystems across the globe are becoming increasingly human-dominated, leading to declines in their biodiversity and ecosystem functioning (Theobald, 2010). Efforts to restore these properties of systems primarily focus on the aboveground plant community (Callaham et al., 2008; Stanturf et al., 2014; Suding et al., 2015). This restoration focus has often led to many positive outcomes, from increases in the strength of carbon (C) and nitrogen (N) sinks (Hooker and Compton, 2003; Houghton and Hackler, 2000) to recovery of herbaceous understories in forests (Duffy and Meier, 1992; Holl and Aide, 2011). Yet, this focus on aboveground plant restoration has also met with failure when soils are ignored (Kardol and Wardle, 2010; Ohsowski et al., 2012). Such failures have led researchers to question the efficacy by which passive (i.e. abandonment) or active restoration might return degraded ecosystems to states more representative of a

\footnotetext{
* Corresponding author at: Department of Soil and Water Systems, University of Idaho, 606 S Rayburn St., Moscow, ID, 83844, USA

E-mail address: mstrickland@uidaho.edu (M.S. Strickland).
} 
system's previous structure and function when belowground components are ignored (Chazdon, 2008; Eviner and Hawkes, 2008; Holl and Aide, 2011).

By overlooking soils and belowground communities (Callaham et al., 2008), particularly soil microbial communities, restoration efforts may fail to restore the major heterotrophs in terrestrial ecosystems and hence system carbon and nutrient cycling (Fierer et al., 2009). In addition, these restoration efforts take a 'field of dreams' approach, that is the restoration of the soil communities will follow aboveground restoration (i.e. planting trees to restore a forest will lead to a forest soil community). As such, knowledge of relationships between aboveground and belowground communities (e.g. plant-soil feedbacks) are ignored, as are the functional implications of effectively restoring soil microbial communities (Strickland et al., 2009; van der Putten et al., 2013; Wubs et al., 2016). For instance, depending on the aboveground community there is the potential that differences in ecosystem function may arise due to differences in the types of mycorrhizal associates, competition between mycorrhizae and saprotrophic fungi, and differing modes of nutrient acquisition (Averill and Hawkes, 2016; Phillips et al., 2013). Ignoring these relationships and their importance to ecosystem function may limit the effectiveness of ecosystem restoration efforts (Callaham et al., 2008; Harris, 2009).

The need to explicitly consider belowground microbial communities in designing restoration efforts is apparent given the fundamental roles played by soil microbial communities. For instance, soil microbial communities are major contributors to the formation of stable soil organic matter, which is a property fundamental to ecosystem health (Cotrufo et al., 2013; Schmidt et al., 2011). Additionally, it is important to consider that belowground microbial communities may be slow to respond to changes in the aboveground community (Kulmatiski and Beard, 2011). This slow response will be particularly apparent when considering slow-growing or dispersal limited microbial groups, such as taxa within the bacterial phylum Verrucomicrobia (Brewer et al., 2016), which are often found in high abundance in undisturbed soils (Fierer et al., 2013). Additionally, legacies of the disturbed condition may lead to unsuitable environmental conditions for some microbes and suitable conditions for others (Hovatter et al., 2011). Intensifying aboveground restoration efforts, then may have little immediate influence and lag in their effect on belowground microbial communities, especially if agricultural legacies and/or soil degradation precede such restoration efforts.

We examined the influence of four aboveground forest restoration treatments (established in 1995) of increasing intensity (Fig. 1) (Stanturf et al., 2009) on soil microbial community structure and function at a previously farmed bottomland site in the Lower Mississippi Alluvial Valley (LMAV). The restoration treatments, from least to most intensive, were i) unassisted recolonization, ii) direct-seeding Nuttall oak (Quercus texana) acorns, iii) planting bare-root Nuttall oak nursery stock, and iv) interplanting eastern cottonwood with oaks. We compared the response of these restoration treatments to adjacent active agricultural sites and remnant bottomland hardwood forest stands. These restoration treatments represented a gradient of restoration intensity from a labor perspective, from an ecological perspective these treatments represented a gradient of both aboveground vertical structure and attempts at jump-starting forest succession (Stanturf et al., 2009). When considering the aboveground restoration success for these treatments, by 1998, four growing seasons after initial establishment, biomass of ground-layer vegetation was highest in the recolonization (i) and direct seeded (ii) treatments and these two treatments had the lowest overstory tree density (De Steven et al., 2015). Plant species diversity changed over time, reflecting successional patterns, but restoration treatments had no significant effect on diversity. Finally, restoration treatments differed in how quickly the trees established forestlike conditions. The cottonwood/oak interplanting (iv) achieved canopy closure within two years (Stanturf et al., 2009), although the cottonwood canopy was relatively open such that sufficient light reached the surface to allow herbaceous species to establish (De Steven et al., 2015). While there has been a significant emphasis on understanding the aboveground effects of restoration at these sites, little attention has been paid to the belowground components.

We determined the effects of intensifying restoration on soil prokaryotic and fungal community composition via marker gene sequencing. We also determined whole microbial community function via catabolic profiling (i.e. multiple substrate-induced respiration) and extracellular enzyme activity. Objectives for the study were to: 1) Determine how different restoration practices influence soil microbial communities in comparison to converted (arable) and target (forest) systems; 2) Determine whether restoration practices have equivalent effects on both the composition and functional capabilities of soil microbial communities; and 3) Determine whether more intense restoration efforts expedite 'recovery' of microbial community composition and function toward a reference end goal. We expected that there would be distinct differences between the restoration treatments, with the most intensive restoration efforts leading to microbial communities most similar to those found in the reference bottomland forest stands. That is, if you build it better, then this will expedite the 'recovery' of the microbial community because of aboveground effects on belowground community structure and function (Gellie et al., 2017; van der Putten et al., 2013; Wardle et al., 2004). Alternatively, we recognized that aboveground restoration intensity might have little influence on microbial community composition and function - potentially due to the primacy of land use legacies in shaping soil communities and processes (Grandy et al., 2009; Johnstone et al., 2016; Keiser et al., 2011). Under such a scenario there would be few differences observed between restoration treatments (i.e. building it better will not expedite the 'recovery' of the microbial community).

\section{Materials and methods}

\subsection{Study site description and experimental design}

For a complete description of the experimental design and establishment see Stanturf et al. (2009). Briefly, all experimental plots were established by May 1995 in Sharkey County, MS $\left(32^{\circ} 58^{\prime} \mathrm{N} 90^{\circ} 44^{\prime} \mathrm{W}\right)$ located within the greater LMAV. Elevations in the experimental plots range from a maximum of $30.9 \mathrm{~m}$ MSL to a minimum of $28.5 \mathrm{~m}$ MSL. Soils at these sites are Vertisols of the Sharkey series (very-fine, smectitic, thermic chromic Epiaquerts) and these sites were historically dominated by bottomland hardwood forests (Stanturf et al., 2000). The entire experimental area was cultivated to soybean (Glycine max) in the year prior to establishment of the restoration treatments, and was disked immediately prior to establishment.

The experiment is a randomized complete block design, with blocks accounting for elevational variation. The treatment plots are $\sim 8$ ha in size and consist of four treatments ranging in restoration intensity from, i) unassisted recolonization, ii) direct-seeding Nuttall oak (Quercus texana) acorns, iii) planting bare-root Nuttall oak nursery stock (i.e. saplings), to iv) interplanting eastern cottonwood (Populus deltoides) with Nuttall oak (Fig. 1). Hereafter, we refer to these restoration treatments as recolonization (i), direct-seed (ii), planted oaks (iii), and interplanted (iv), respectively. In particular, the interplanted (iv) treatment aims to establish an early successional, arbuscular mycorrhizal (AM) fungal associated tree species, eastern cottonwood, along with the later successional, ectomycorrhizal associated Nuttall oak. This interplanting leads to a more rapid increase in vertical structure and a stratified canopy, which has been shown to increase bird species richness associated with this treatment (Hamel, 2003). Other than the interplanted (iv) treatment, the other treatments had not reached canopy closure at the time of sampling (i.e. 2010).

Soils were sampled in Spring 2010 and Winter 2011-to account for potential turnover in the microbial community between the growing and non-growing season - from $5 \times 5 \mathrm{~m}$ subplots located within each 


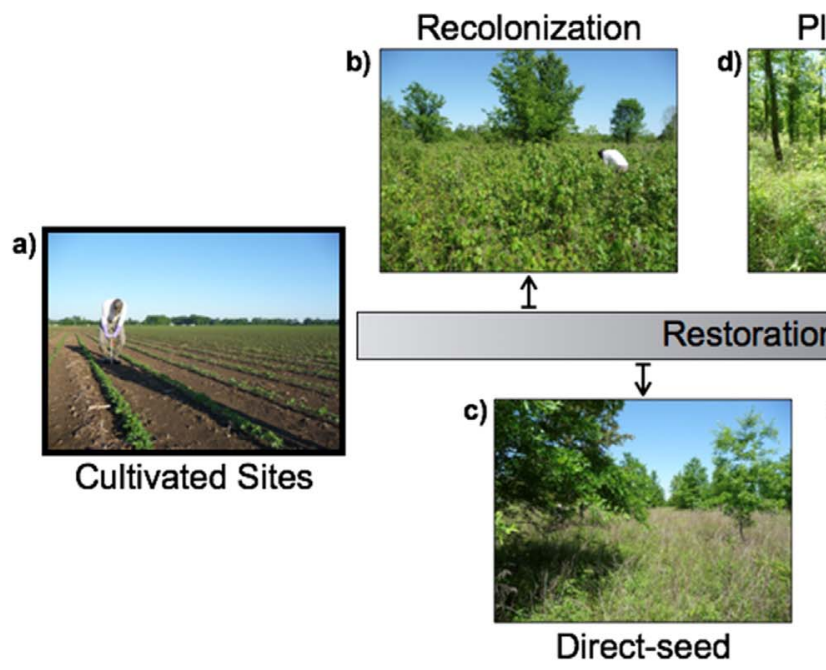

Planted oaks

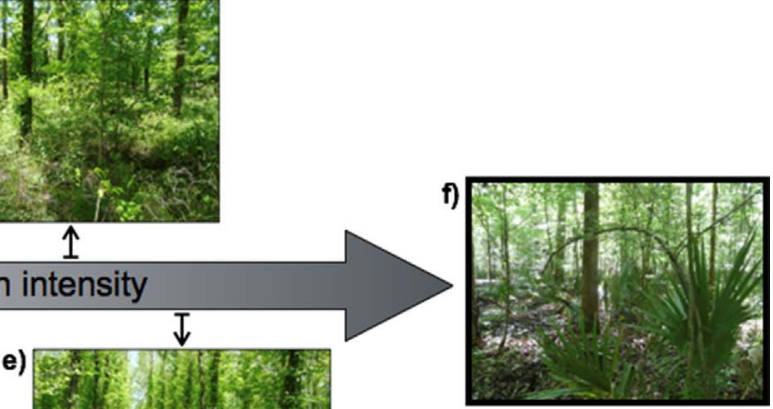

Remnant forest

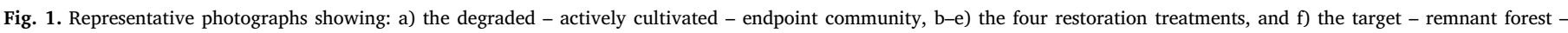

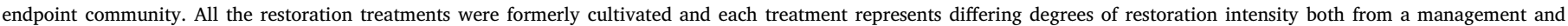

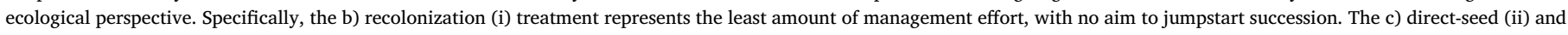

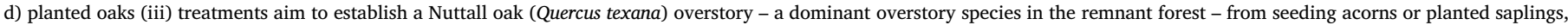

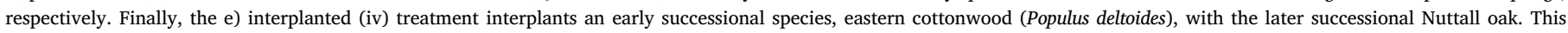

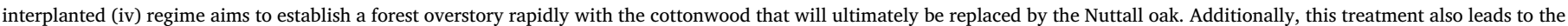
development of a stratified canopy.

of the larger $\sim 8$ ha restoration plots (Fig. S1). Additional soil samples were taken from an adjacent cultivated site (i.e. the starting point for restoration) and a remnant forest stand (i.e. the target reference condition) within the Delta National Forest ( $\mathrm{n}=3$ per land use; Fig. 1). These additional samples served as end points of the continuum from cultivated to undisturbed, allowing us to determine the relative efficacy of the four restoration treatments. Bulk soil sampling involved taking 5 cores $(0-7.5 \mathrm{~cm}$ depth, after removing surface material) from randomly-selected locations within each subplot. The 5 cores were pooled by subplot giving us one sample per treatment replicate (i.e. 15 total samples per season, barring the loss of one sample by UPS during transit). Bulk soil was then sieved $(4.75 \mathrm{~mm})$, homogenized, and stored at either $4{ }^{\circ} \mathrm{C}$ for determination of soil characteristics and catabolic profiles, or $-80^{\circ} \mathrm{C}$ for determination of microbial community composition and extracellular enzyme activity (note: while no formal assessment of storage at $-80{ }^{\circ} \mathrm{C}$ has been conducted on enzyme activity, we note little difference between the samples in this study and similar samples stored at $-20^{\circ} \mathrm{C}$ ).

\subsection{Determination of microbial community composition}

To assess microbial community composition, we determined both prokaryotic (bacteria and archaea) and fungal community composition via marker gene sequencing. DNA was extracted from the soils using the PowerSoil DNA extraction kit (MoBio Laboratories, Inc.) and prepared for sequencing as in Fierer et al. (2012) and McGuire et al. (2013). Community composition was assessed via amplification of the V4-V5 region of the bacterial/archaeal 16S gene and the fungal ITS1 region using the primer sets, 515f/806r (Caporaso et al., 2011) and ITS1-F/ ITS2 (McGuire et al., 2013; White et al., 1990) containing DNA barcodes unique to each sample. For each marker gene target, amplicons from all samples were pooled, cleaned, and sequenced on a separate lane of an Illumina HiSeq2000 instrument using a $2 \times 100$ bp pairedend kit.

Raw forward sequence reads were processed following the UPARSE pipeline (Edgar, 2013) as implemented in Prober et al. (2015). Prior to sequence clustering at $97 \%$ similarity, sequences were filtered using a maximum expected error rate of 0.5 , and singleton sequences were removed. Clusters [i.e. operational taxonomic units (OTUs)] were removed if they were not within $75 \%$ similarity to sequences in the
Greengenes (McDonald et al., 2012) or UNITE (Abarenkov et al., 2010) databases for 16S rRNA gene and ITS region sequences, respectively. These databases were also used for training the RDP classifier (Wang et al., 2007) when assigning taxonomy to each OTU. OTUs were removed if they were not assigned phylum level taxonomy. To account for differences in the number of sequences per sample, samples were rarefied to 98,000 and 26,000 sequences for 16S rRNA gene and ITS region sequences. Fungal OTUs were assigned to putative functional guilds based on their taxonomy using FunGuild (Nguyen et al., 2016).

\subsection{Determination of microbial community function}

To determine microbial community function, we assessed both catabolic profiles and extracellular enzyme activity. For catabolic profiles, we used a modified version of the multiple substrate-induced respiration technique described by Degens and Harris (1997). This method enables us to determine differences in substrate utilization between microbial communities by directly measuring microbial respiration. Briefly, we amended $4 \mathrm{~g}$ dry weight equivalent soil (1 analytical rep per solution) with $8 \mathrm{~mL}$ solutions of glucose, sucrose, glycine, oxalic acid, citric acid, chitin, and cellulose (27, 51, 2, 18, 38, 96, $96 \mathrm{mg}$ of substrate $\mathrm{g} \mathrm{soil}^{-1}$, respectively). Each solution was adjusted to $\mathrm{pH} 6$ using $\mathrm{NaOH}$ or $\mathrm{HCl}$ prior to addition. After a $1 \mathrm{~h}$ pre-incubation with shaking, the soil slurries (i.e., soil and solution combinations) were incubated for $4 \mathrm{~h}$ at $20^{\circ} \mathrm{C}$, except for chitin and cellulose which were incubated for $24 \mathrm{~h}$. After incubation, respiration for each amendment was determined on an infrared gas analyzer (IRGA; Model LI-7000, LiCor Biosciences, Lincoln, NE, USA) using a static incubation technique.

In addition to catabolic profiles, we also assessed microbial function via extracellular enzyme activity. Extracellular enzymes produced via microbes are directly responsible for the degradation of plant material and nutrient acquisition, and as such can inform us regarding the response of soil microbial communities to change in their environment (Burns et al., 2013; DeForest, 2009). Following the procedure outlined by DeForest (2009), we determined activity of the following hydrolytic enzymes: cellobiohydrolase (involved in cellulose degradation), acid phosphatase (hydrolyze phosphomonoesters), $N$-acetyl- $\beta$-glucosaminidase (involved in chitin degradation), and $\beta$-glucosidase (hydrolyze cellulose, releasing glucose) as fluorescence of the methylumbelliferyl (MUB)-linked substrates $\beta$-D-cellobioside, phosphate, $N$-acetyl- $\beta$-D- 
glucosaminide, and $\beta$-D-glucopyranoside, respectively. After homogenizing $\sim 1 \mathrm{~g}$ of dry weight soil in $100 \mathrm{~mL}$ of sodium acetate buffer $(\mathrm{pH}=5.8)$, the resultant soil slurry was combined with $50 \mu \mathrm{L}$ of substrate in a 96-well microplate. After incubation, fluorescence was measured at excitation wavelength of $360 \mathrm{~nm}$ and an emission wavelength of $450 \mathrm{~nm}$ on a flurometric plate reader (Model Infinite M200; Tecan Group Ltd, Männedorf, Switzerland). Enzyme activity is expressed as micromoles of substrate converted $\left(\mu \mathrm{mol} \mathrm{h}^{-1} \mathrm{~g}\right.$ dry wt soil $^{-1}$ ).

For each of the collected soil samples, we also determined active microbial biomass, relative amounts of mineralizable- $\mathrm{C}$, and soil $\mathrm{pH}$. Active microbial biomass was determined via substrate induced respiration (SIR) following Strickland et al. (2010b). This procedure is similar to the determination of catabolic profiles, except autolyzed yeast is used as the substrate. Mineralizable-C was determined by measuring total $\mathrm{CO}_{2}$ emissions over the course of a $60 \mathrm{~d}$ incubation. Soils ( $8 \mathrm{~g}$ dry weight) were maintained at $65 \%$ water-holding capacity and $20^{\circ} \mathrm{C}$ with respiration across this time period determined (soils were measure 8 times) using the static incubation procedure described for catabolic profiles. Total mineralizable-C was estimated by integrating $\mathrm{CO}_{2}$ production across time. Soil $\mathrm{pH}\left(1: 1\right.$, soil: $\mathrm{H}_{2} \mathrm{O}$ by volume) was determined on a benchtop $\mathrm{pH}$ meter.

\subsection{Statistical analyses}

The effect of restoration treatments on soil $\mathrm{pH}$, mineralizable-C, SIR, absolute respiration of catabolic profile substrates, and total hydrolytic enzyme activity (determined as the sum of cellobiohydrolase, acid phosphatase, $N$-acetyl- $\beta$-glucosaminidase, and $\beta$-glucosidase) was determined using a blocked analysis of variance (ANOVA). Total hydrolytic enzyme activity was assessed because it gives us a coarse indication of changes in total microbial allocation to extracellular enzymes. To gain finer insight into differences in enzyme activity across treatments, we also assessed enzyme acquisition ratios (Sinsabaugh et al., 2008). We also determined both the proportional respiration and activity for catabolic profiles and enzyme activity, respectively. We standardized by proportion because we were interested in detecting functional shifts in the microbial communities, as well as increases or decreases in absolute respiration rates and activity. We analyzed Euclidean distance matrixes constructed using these proportions via a permutational MANOVA (perMANOVA) and visualized using principal coordinates analysis. Pairwise comparisons between restoration treatments were also analyzed via perMANOVA and we tested for homogeneity of dispersions from the centroids via betadisper tests (Anderson et al., 2008). Prokaryotic and fungal communities (at the level of OTU) were similarly analyzed, except Bray-Curtis distances were used in these analyses. To determine which fungal or prokaryotic taxa contributed to differences between restoration treatments, the percentage contribution of taxa to overall Bray-Curtis dissimilarity between treatments was determined using the SIMPER (similarity percentages) command in Primer (Clarke, 1993). ANOVA was conducted in R ( R Core Team, 2012) and analyses of the microbial community, catabolic profiles, and extracellular enzyme activity were conducted in Primer (Clarke and Gorley, 2006).

\section{Results}

\subsection{Microbial community composition}

We examined the effect of restoration treatments on soil microbial community composition and found significant differences in soil prokaryotic community composition (Fig. 2A, Table S1) among treatments (pseudo- $F_{5,20}=4.08 ; \quad P<0.001$ ) and between sampling dates (pseudo- $F_{1,20}=2.76 ; P<0.001$ ), but no interaction was observed (pseudo- $F_{5,20}=1.01 ; P=0.47$ ). Centroid dispersions did not differ between treatments $\left(F_{5,28}=1.24 ; P=0.60\right)$ indicating that replicates
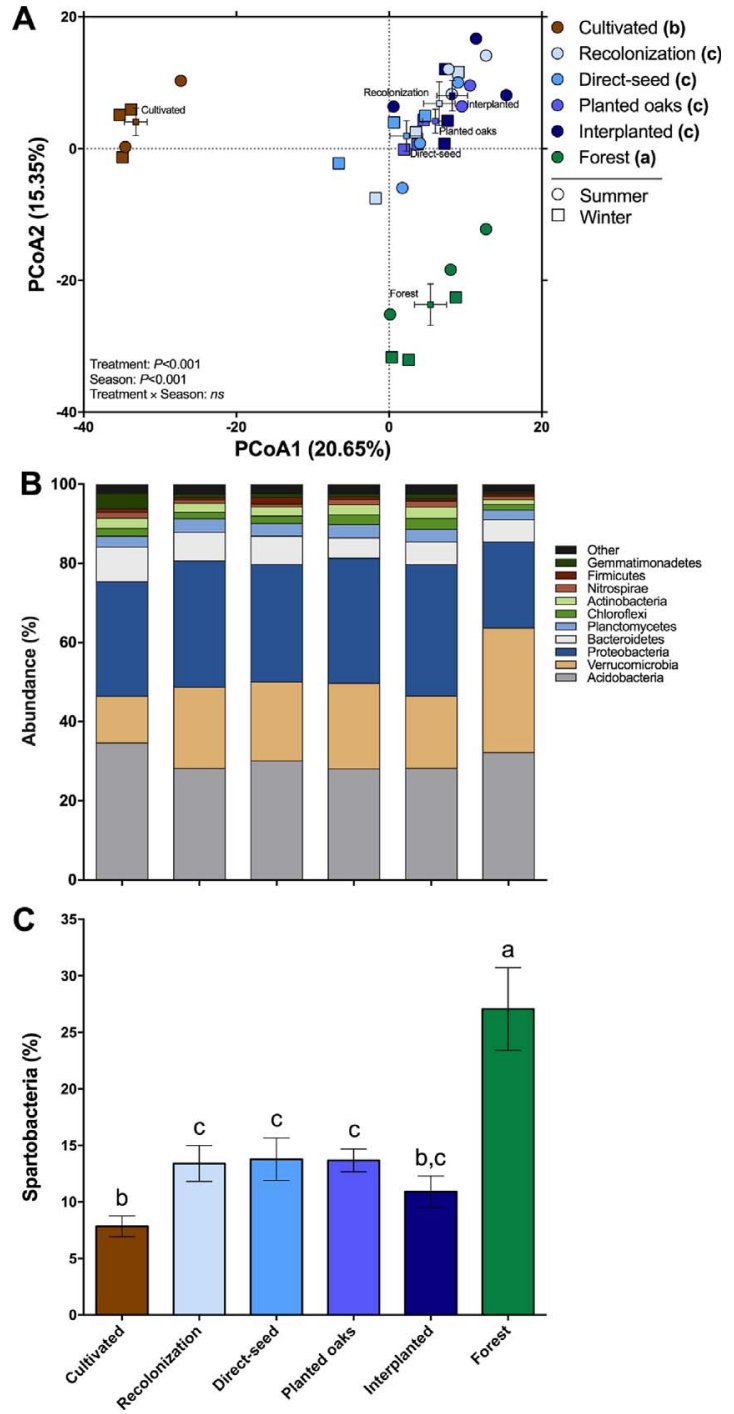

Fig. 2. Bacterial community composition associated with the four restoration treatments and the two reference sites. A) An ordination plot showing principal coordinates analysis of Bray-Curtis distances between bacterial communities. The centroid \pm 1 S.E. for each treatment is plotted as a square, also denoted by either a circle or square are communities associated with either the summer or winter sampling dates, respectively. Cultivated sites are shown in brown, remnant forests in green, and restoration sites - in the order recolonization (i), direct-seed (ii), planted oaks (iii), interplanted (iv) - are a gradient of light to dark blue. In the figure key, letters denote significant pairwise differences between treatments as determined via permutational MANOVA. B) A bar chart showing the mean relative abundance, across both sampling dates, of the major bacterial phyla associated with each treatment. C) Bar chart showing the relative abundance of Verrucomicrobia family Spartobacteriaceae across the treatments. Shown are means \pm 1 S.E.; letters denote significant pairwise differences determined via Tukey's HSD test. (For interpretation of the references to color in this figure legend, the reader is referred to the web version of this article.)

associated with a particular treatment were not more or less variable when compared to replicates from other treatments. Treatment differences were due to all four restoration treatments differing from both the remnant forest and cultivated sites; and differences between remnant forest and cultivated sites (Fig. 2A and B). The prokaryotic communities in the restoration treatments did not differ from each other (Fig. 2A and B). At the phylum level, the drivers of the differences between treatments were the Acidobacteria and Verrucomicrobia. The relative abundance of taxa within the Acidobacteria phylum was greatest in both the remnant forest $(32.2 \%)$ and cultivated sites (34.6\%), and lowest in the restoration treatments $\left(28.1-30.1 \%\right.$; Fig. $2 \mathrm{~B} ; F_{5,20}=4.75$; $P<0.01)$. Verrucomicrobia exhibited the greatest relative abundance 

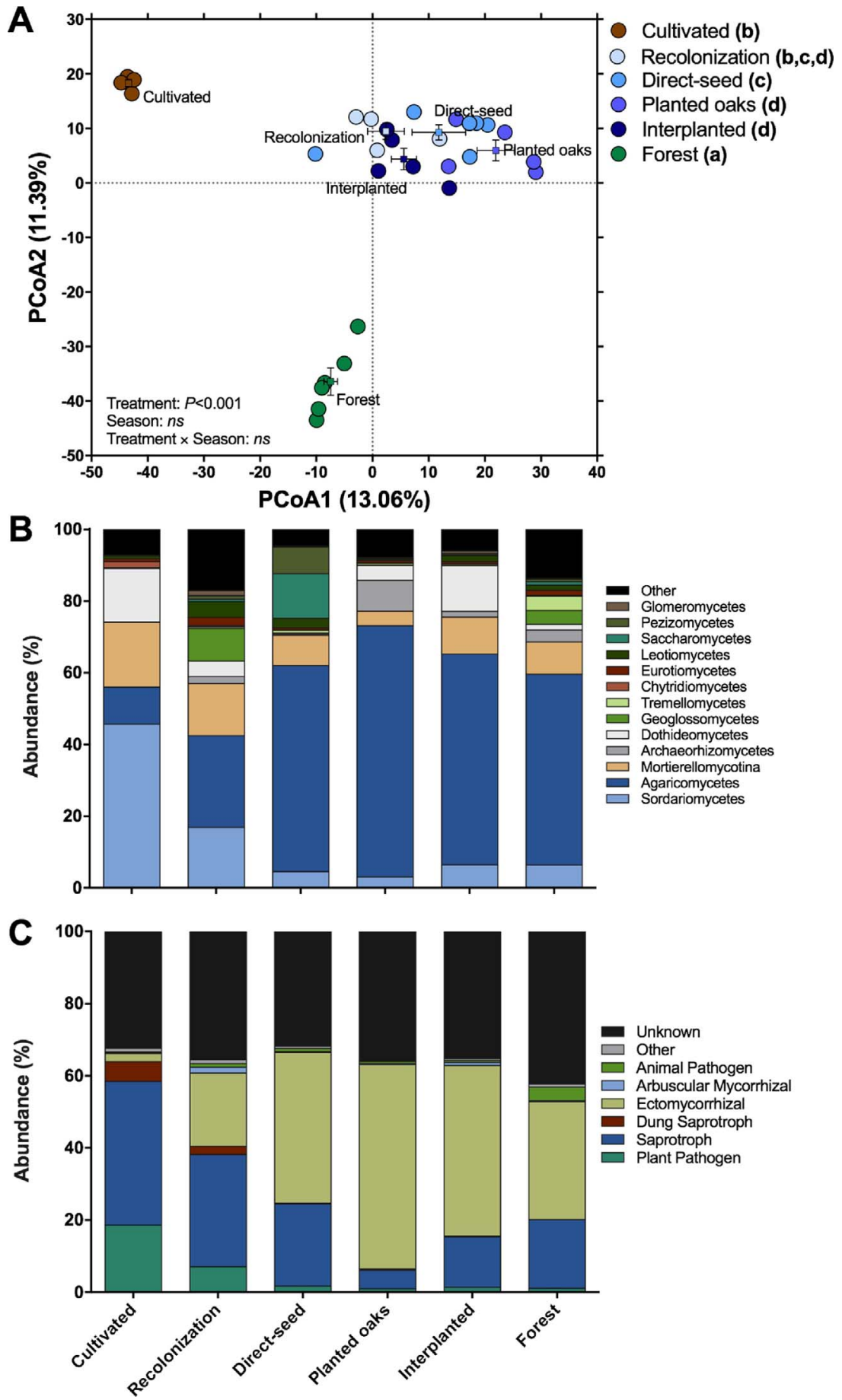

Fig. 3. Fungal community composition associated with the four restoration treatments and the two reference sites. A) An ordination plot constructed via principal coordinates analysis of Bray-Curtis distances between fungal communities. The centroid \pm 1 S.E. for each treatment is plotted as a square. Symbols per Fig. 1, with the exception that sampling dates are not differentiated given no difference in fungal community composition between the summer and winter. In the figure key, letters denote significant pairwise differences between treatments as determined via permutational MANOVA. B) A bar chart showing the mean relative abundance of the major fungal classes associated with each treatment. C) A bar chart showing the mean relative abundance of fungal ecological strategies associated with each treatment. in the remnant forests $(31.4 \%)$, intermediate abundance in the restoration treatments $(18.3-21.6 \%)$, and the lowest abundance in the cultivated sites (11.8\%; Fig. 2B). Spartobacteria the dominant Verrucomicrobia class was the primary driver of these differences, accounting for $\sim 8 \%$ of the dissimilarity, determined via SIMPER, between remnant forests and both cultivated sites and restoration treatments. In fact, the relative abundances of the Spartobacteria in the remnant forests were $\sim 2$-fold greater than the restoration treatments and 3.5-fold greater than in the soils collected from the cultivated sites (Fig. 2C; $F_{5,20}=27.5 ; P<0.001$ ).

We observed significant differences in fungal community composition among treatments (pseudo- $F_{5,16}=2.65 ; P<0.001$ ) but not between sampling date (pseudo- $F_{1,16}=1.11 ; P=0.33$ ), or the interaction between treatment and sampling date (pseudo- $F_{5,16}=0.85$;
$P=0.92$; Fig. 3A, Table S2). Centroid dispersions did not differ between treatments $\left(F_{5,24}=3.60 ; P=0.09\right)$. For treatment differences, remnant forests differed from all four restoration treatments and the cultivated sites; cultivated sites differed from all but the recolonization (i) treatment; and the planted oaks (iii) treatment differed from the recolonization (i) treatment (Fig. $3 \mathrm{~A}$ and $\mathrm{B}$ ). These differences were primarily due to greater relative abundances of members of the class Sordariomycetes in the cultivated sites (45.7\%), intermediate abundances in the recolonization (i) treatment $(16.9 \%)$, and the lowest abundances in the remaining restoration treatments and remnant forests (3.0-6.4\%; Fig. 3B). We further examined differences amongst fungal communities by assigning genera to putative functional guilds (Nguyen et al., 2016). Many fungal OTUs (32-42\%) could not be assigned to a specific guild, however, patterns did emerge for those taxa 
A

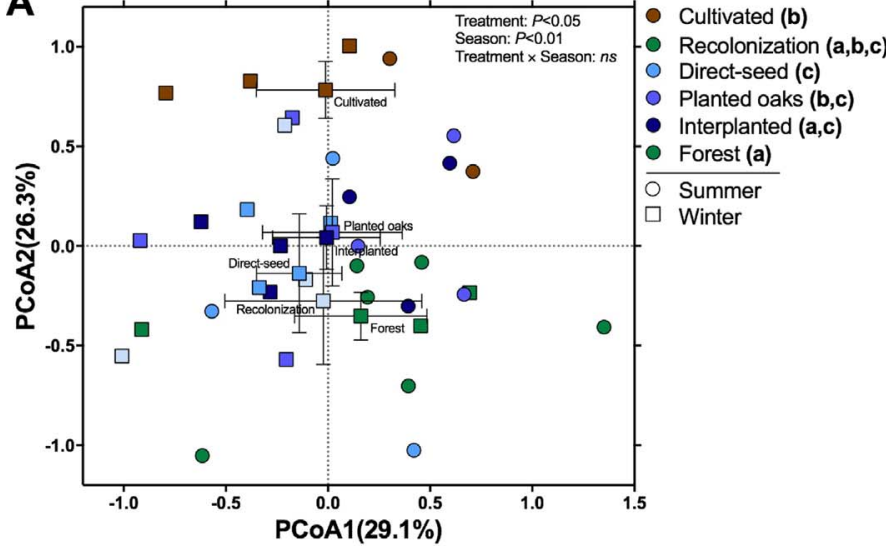

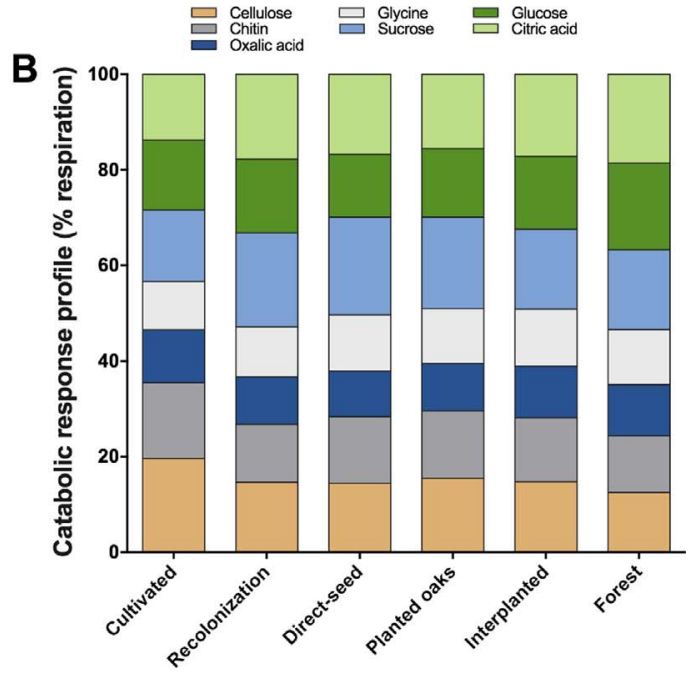

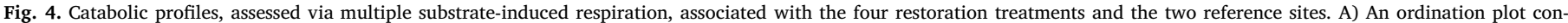

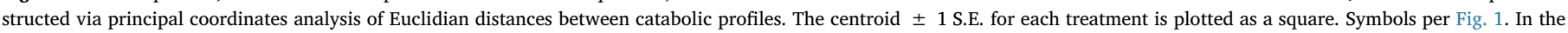

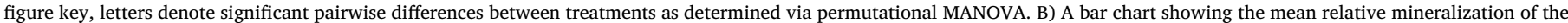

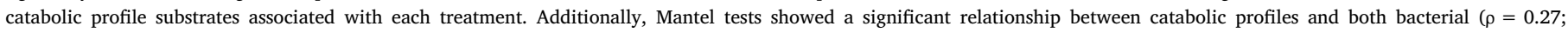
$P<0.01)$ and fungal community $(\rho=0.23 ; P<0.01)$ distance matrixes.

that could be assigned (Fig. S2). We observed the greatest abundances of ectomycorrhizae in the remnant forests (19\%) and the three restoration treatments that contained oak trees (42-57\%); intermediate abundances in the recolonization (i) treatment (20\%); and nearly none $(2.3 \%)$ in the cultivated sites (Fig. 3C). While the cultivated sites and recolonization (i) treatments had a lower relative abundance of ectomycorrhizae, these sites tended to have a greater abundance of saprotrophic, dung saprotrophic, and plant pathogenic fungi when compared to the remaining treatments (Fig. 3C). Additionally, the recolonization (i) treatment had the greatest abundance of arbuscular mycorrhizal fungi and the remnant forests had the greatest abundance of animal pathogenic fungi (Fig. 3C).

\subsection{Microbial community function}

Microbial community function was assessed via both catabolic profiles and extracellular enzyme activity. For catabolic profiles (Fig. 4A, Table S3), significant differences were observed between treatments (pseudo- $F_{5,21}=2.03 ; P<0.05$ ) and sampling date (pseudo- $F_{1,21}=4.55 ; P<0.01$ ), but not for the interaction (pseudo$F_{5,21}=1.22 ; P=0.23$ ). Centroid dispersions did not differ between treatments $\left(F_{5,29}=0.50 ; P=0.85\right)$. Considering differences between treatments, remnant forest plots differed from the cultivated sites and both the direct-seed (ii) and planted oak restoration treatments, but had similar catabolic profiles to the recolonization (i) and interplanted (iv) treatments (Fig. 4A and B). The cultivated sites had similar catabolic profiles to both the planted oak and recolonization (i) treatments (Fig. 4A and B). No differences in catabolic profiles were noted between the four restoration treatments (Fig. 4A and B). The observed differences were primarily driven by the greatest proportional respiration of cellulose associated with the cultivated sites; intermediate proportional respiration for the restoration treatments; and the lowest proportional respiration for the remnant forests (Fig. 4B). Remnant forests exhibited greater proportional respiration for glucose and citric acid, followed by intermediate values for the restoration treatments, and the lowest values observed in the cultivated sites (Fig. 4B). To determine whether function was related to microbial community composition, we examined relationships between catabolic profiles and both prokaryotic and fungal community composition via Mantel tests. We found that both prokaryotic $(\rho=0.27 ; \quad P<0.01)$ and fungal $(\rho=0.23$; $P<0.01)$ community composition was correlated to function assessed via catabolic profiles.

When considering the absolute respiration of catabolic profile substrates, as opposed to proportional respiration, we observed significant and marginally significant differences between treatments for all the substrates except cellulose and chitin (Fig. S3). For the absolute mineralization of those substrates that differed by treatment, we generally found that remnant forests exhibited the greatest mineralization, restoration treatments were intermediate and exhibited no differences amongst themselves, and cultivated sites exhibited the lowest absolute mineralization rates (Fig. S3).

For profiles of extracellular enzyme activity (Fig. 5A; Table S4), significant differences were observed for treatments (pseudo$F_{5,21}=3.13 ; \quad P<0.01$ ) but not for sampling date (pseudo$\left.F_{1,21}=0.73 ; P=0.48\right)$ or the interaction between treatment and sampling date (pseudo- $F_{5,21}=1.92 ; P=0.08$ ). Centroid dispersions did not differ between treatments $\left(F_{5,29}=1.37 ; P=0.33\right)$. Considering differences between treatments, remnant forests differed from the cultivated sites and all of the restoration treatments except the planted oak treatment (Fig. 5A and B). Cultivated sites differed from the planted oak and recolonization (i) treatments but were similar to the direct-seed (ii) and interplanted (iv) treatments (Fig. 5A and B). Except for differences between the recolonization (i) and direct-seed (ii) treatment, all of the restoration treatments exhibited similar extracellular enzyme profiles (Fig. 5B). These differences were primarily driven by a greater and lesser proportion of acid phosphatase and $n$-acetyl- $\beta$-glucosaminidase activity, respectively, in the cultivated sites versus the remnant forests, and generally intermediate levels in the restoration treatments (Fig. 5B).

Determining N:P enzyme acquisition ratios allowed us to estimate the nutrient status of the microbial community, with a greater $\mathrm{N}: \mathrm{P}$ acquisition ratio indicating greater enzyme allocation aimed at acquiring $\mathrm{N}$ relative to $\mathrm{P}$. Overall differences between treatments were observed $\left(F_{5,21}=7.41 ; P<0.001\right.$; Fig. S4), with the cultivated sites tending to have the lowest N:P ratio and the remnant forests having the greatest. Of the restoration treatments, only the planted oak (iii) treatment was significantly different from the cultivated sites and similar to the remnant forests (Fig. S4). All other restoration treatments differed from the remnant forests but had similar N:P acquisition ratios to the cultivated sites. In addition to differences between enzyme profiles and acquisition ratios, we also found differences in total hydrolytic enzyme activity between treatments $\left(F_{5,21}=5.75 ; P<0.01\right)$ and 

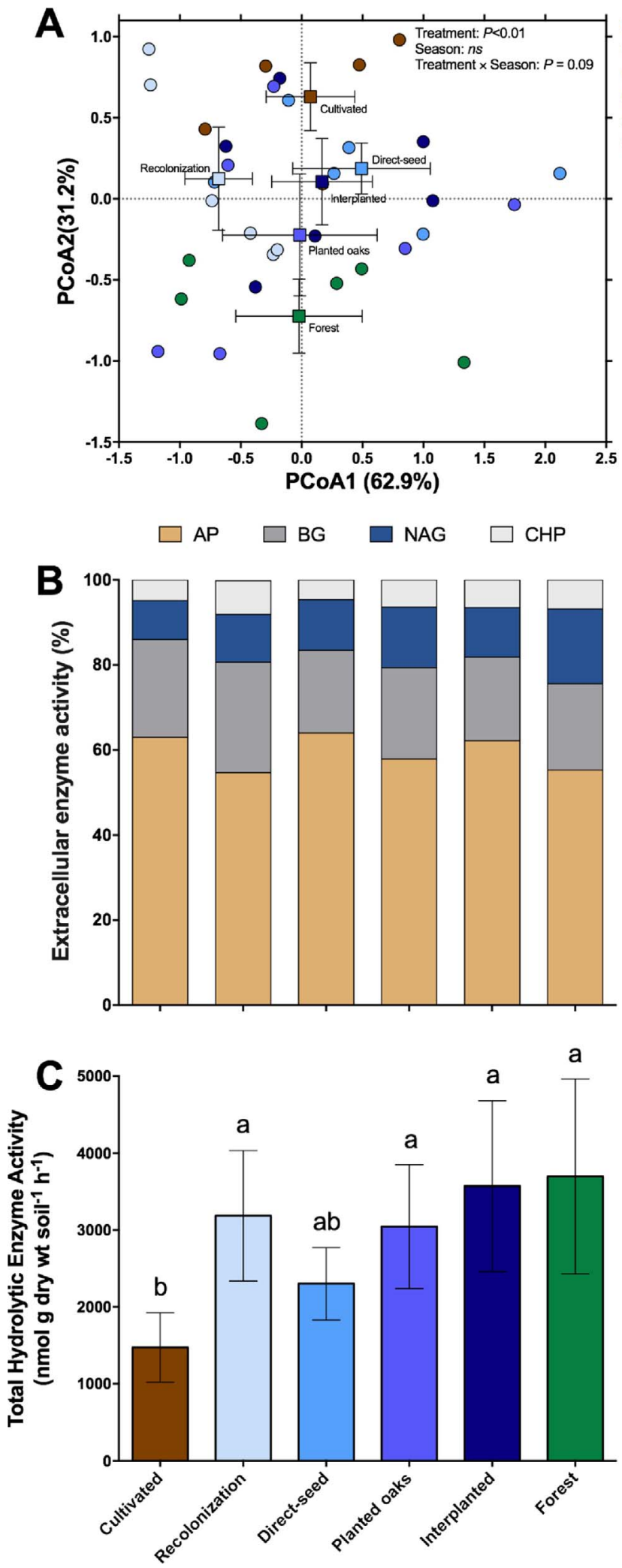

sampling date $\left(F_{1,21}=42.29 ; P<0.001\right.$; i.e. greater in the summer than the winter), but not the interaction between the two $\left(F_{5,21}=0.97\right.$; $P=0.46)$. Specifically, the remnant forests and restoration treatments (except for the direct seed treatment, which was intermediate) exhibited greater activity than the cultivated sites (Fig. 5C). In fact, an $\sim 2$-fold increase in activity was noted for the forests and restoration treatments compared to the cultivated sites. Like catabolic profiles, we
Fig. 5. Extracellular enzyme activity associated with the four restoration treatments and the two reference sites. A) An ordination plot constructed via principal coordinates analysis of Euclidian distances between profiles of extracellular enzyme activity. The centroid \pm 1 S.E. for each treatment is plotted as a square. Symbols per Fig. 2. In the figure key, letters denote significant pairwise differences between treatments as determined via permutational MANOVA. B) A bar chart showing the relative activity of each hydrolytic enzyme. C) Bar chart showing total hydrolytic enzyme activity for each treatment. Shown are means \pm 1 S.E.; letters denote significant pairwise differences determined via Tukey's HSD test. Additionally, Mantel tests showed a significant relationship between the extracellular enzyme distance matrix and fungal $(\rho=0.19$; $P<0.05)$ community distance matrix examined relationships between enzyme profiles and both prokaryotic and fungal community composition via Mantel tests. We found that fungal $(\rho=0.19 ; P<0.05)$ but not prokaryotic community composition ( $\rho=0.14 ; P=0.07$ ) was related to enzyme profiles.

When examining SIR biomass, we observed no treatment effects (Table S5; $F_{5,21}=1.46 ; P=0.25$ ) but SIR biomass tended to be greater during the summer sampling date compared to the winter 
$\left(F_{1,21}=104.13 ; P<0.001\right)$. For soil $\mathrm{pH}$, only treatment effects were observed (Table S5; $F_{5,21}=9.96 ; P<0.001$ ), with lower soil $\mathrm{pH}$ in the remnant forests and cultivated sites and higher $\mathrm{pH}$ in the restoration treatments (Fig. 1C). For mineralizable-C, significant treatment (Table S5; $\left.\quad F_{5,21}=9.98 ; \quad P<0.001\right)$ but not sampling date effects $\left(F_{1,21}=0.00 ; P=0.99\right)$ were observed. Specifically, mineralizable-C was lowest in the cultivated sites and greatest in the forests and restoration treatments.

\section{Discussion}

Here we examined the responses of soil microbial community structure and function to restoration treatments of varying intensity aimed at restoring bottomland forest ecosystems. Our goals were to determine if, and to what degree, these restoration practices influence soil microbial communities in comparison to reference degraded and target systems (i.e. cultivated sites and remnant forests, respectively). In most instances, we observed that soil microbial communities responded similarly across all four restoration treatments (although we do not know if this similarity was reached at the same time scale) regardless of whether composition or function was being observed. Additionally, community composition and function of the restoration treatments typically exhibited an intermediate response when compared to the cultivated sites and forest remnants. This suggests that after $\sim 16$ years since establishment of the restoration treatments, the act of agricultural abandonment likely had the most marked influence on soil microbial communities, while manipulations of aboveground community structure via seeding or planting of tree species played a relatively minor role.

The intermediate response of the restoration treatments was apparent when considering soil prokaryotic communities (Fig. 2), particularly in the case of the phylum Verrucomicrobia. This phylum tended to be in greatest abundance in the forest remnants, lowest abundance in the cultivated sites, and of intermediate abundance in all of the restoration treatments. Verrucomicrobia tend to be responsive to soil disturbance, often exhibiting lower abundance under intensively managed conditions (Brewer et al., 2016; Buckley and Schmidt, 2001; Fierer et al., 2013). The increase in Verrucomicrobia in the restoration treatments compared to the cultivated sites is likely driven by the cessation of active agricultural practices (Buckley and Schmidt, 2001). However, after $\sim 16$ years of agricultural cessation, the abundance of Verrucomicrobia was still $\sim 10 \%$ less than that observed in the forest plots. For family Spartobacteriaceae of the Verrucomicrobia, relative abundance was still $\sim 15 \%$ less than that observed in the forest plots. Unless there is a barrier preventing colonization (although we note that most of the dominant OTUs were present in both the remnant forests and restoration treatments), this suggests that the response of some bacterial phyla may take several years to decades before recovering to the relative abundances observed in the restoration target. From the prokaryotic community perspective, the expectation of the 'field of dreams' - if you build it they will come - ideology of restoration ecology (Hilderbrand et al., 2005) may not see players take the field immediately, if at all. This lag could be driven by slow changes in some soil physical-chemical properties (e.g. soil $\mathrm{pH}$ in this study) after the cessation of agricultural practices to re-establish forest. It could also be due to dispersal limitation of prokaryotic taxa. That is, they fail to colonize the sites even when habitat conditions are successfully restored, such as the similarity in mineralizable-C observed between the restoration treatments and the remnant forests.

While the increase in relative abundance of Verrucomicrobia in the restoration treatments was indicative of a change away from the cultivated sites towards the target forest remnants, this was not necessarily the case across all bacterial taxa. Specifically, the relative abundance of phylum Acidobacteria was greatest in the cultivated sites and forest remnants, and lowest in the four restoration treatments. Taken together, these results suggest that some bacterial taxa may change in abundance such that they become more similar to the restoration target upon cessation of agriculture (i.e. Verrucomicrobia), whereas others actually diverge from that target during the same time frame (i.e. Acidobacteria). These observations underscore the dynamic nature of soil microbial community composition and suggests that different components of the community may require dramatically different timescales to respond to cessation of cultivation and/or restoration treatments.

Soil fungal community composition tended to be similar across the restoration treatments (Fig. 3). One exception to this was a significant difference noted between the recolonization (i) treatment and the planted oak (iii) treatment. When compared to the reference communities, none of the restoration treatments were compositionally similar to the remnant forests and only the recolonization (i) treatment was similar to the cultivated sites. Across all the restoration treatments and the reference communities, compositional differences appear to be largely a product of tree establishment and/or the cessation of agriculture. That is, in the three restoration treatments where trees were established (i.e. direct-seed (ii), planted oak, and interplanted (iv)) and the remnant forests, class Agaricomycetes tended to dominate and class Sordariomycetes tended to be found in lower abundance when compared to the cultivated sites and recolonization (i) treatment. Similar patterns have been observed by Lauber et al. (2008) and Leff et al. (2015), where class Sordariomycetes - which encompasses a broad array of functional groups (Zhang and Wang, 2015) - declined with decreasing nutrient availability, specifically phosphorus (P), across a land use gradient from agricultural sites to forests. The Agaricales of class Agaricomycetes show the opposite pattern (Lauber et al., 2008). Patterns of fungal community composition are even more striking when fungal genera are assigned to ecological strategies (Tedersoo et al., 2014). Not surprisingly, where Nuttall oak was established, ectomycorrhizal fungi represented the dominant ecological strategy and as such has the potential to influence ecosystem function via competition with saprotrophs (Averill and Hawkes, 2016). More surprising was the observation that with tree planting, fungal plant pathogens were found in lower relative abundance when compared to the cultivated sites or the recolonization (i) treatment (Fig. 3C). Together these findings suggest that planting trees may actively promote ectomycorrhizal fungi (Phillips et al., 2013) as well as decrease burdens associated with plant pathogens (Wall et al., 2015).

When considering microbial community function via catabolic profiles and extracellular enzyme activity, we again observed very few differences amongst the restoration treatments (Fig. 4). For catabolic profiles, all of the restoration treatments exhibited similar profiles to each other and only the recolonization (i), albeit also similar to the reference cultivated site, and interplanted (iv) treatments were similar to the remnant forests. These differences in catabolic profiles are due to greater, intermediate, and lower proportional mineralization of chitin and cellulose in the cultivated sites, restoration treatments and forest plots, respectively, with the opposite observed for glucose and citric acid. While the greater proportional mineralization of cellulose and chitin in the cultivated sites may be surprising, it is ultimately due to insignificant pairwise differences between treatments when considering the absolute mineralization of these two substrates. The lack of difference between treatments may be related to the chemical recalcitrance of these compounds. By contrast, differences in absolute mineralization were noted for the more labile catabolic profile substrates. The greater mineralization of these labile substrates in the remnant forests and restored treatments, compared to the cultivated sites, may be indicative of the microbial communities' increased utilization of root exudates (Strickland et al., 2015) following the establishment of perennial plants. This finding underlies the importance for microbial function of establishing perennial plant communities early in the restoration process. However, the specific composition of the plant community may be less important given the commonality of the major constituents of root exudates across plant species (de Graaff et al., 2010). Expediting root 
exudation will also prove important if the restoration management goal is to increase soil C, because these labile root inputs are now considered important precursors to the formation of stable soil organic C (Grandy and Neff, 2008). Higher rates of root exudation, in combination with the cessation of tillage, therefore likely explain why the restored and remnant forests had similar amounts of mineralizable-C, and greater amounts compared to the cultivated sites (Table S5). Yet, changes in the mineralization of these potential root exudates may also be driven by prokaryotic and fungal community composition (Fig. 2), suggesting that deliberate manipulations of the whole microbial community may also elicit a more rapid response in this function (Wubs et al., 2016).

For extracellular enzymes, the restored sites were again very similar with only the recolonization (i) treatment differing from the direct-seed (ii) treatment (Fig. 5). Only the planted oak treatment exhibited a similar enzyme profile to the remnant forests, whereas the direct-seed (ii) and interplanted (iv) treatments were similar to the cultivated sites. Differences in acid phosphatase activity between treatments may suggest greater P limitation in the cultivated sites, intermediate limitation in the restored sites, and the least limitation in the remnant forest plots. Differences in $n$-acetyl- $\beta$-glucosaminidase activity suggests the opposite for $\mathrm{N}$ limitation and is further verified by the low enzyme N:P acquisition ratios in the cultivated plots (Fig. S2). These differences are likely due to $\mathrm{N}$ inputs in the cultivated sites and also highlight that such inputs may have a long-standing legacy for microbial function in restored sites, as observed by others (Foster et al., 2003; Strickland et al., 2010a). While enzyme profiles of the restored sites differed from the remnant forests, total hydrolytic enzyme activity was similar to the forests and tended to be greater than the cultivated sites. This increase in enzyme activity may ultimately be tied to the greater relative abundance of ectomycorrhizal species (especially given no differences in total active microbial biomass among treatments) in the restored and forest sites compared to the cultivated sites (Phillips et al., 2013). Additionally, extracellular enzyme profiles were also correlated with fungal community composition, suggesting, similarly to catabolic profiles, that manipulations of microbial community may lead to more rapid convergence of function towards a restoration target.

Often restoration practices focus on aboveground plant communities. At our experimental site this focus on plant community restoration has led to the successful recovery of bird species diversity and improvements in canopy structure (Hamel, 2003; Stanturf et al., 2009). Yet, this focus typically ignores the dominant heterotrophs in these systems, soil microbial communities (Callaham et al., 2008; Stanturf et al., 2014). Here we demonstrate that a focus on intensifying aboveground restoration and a reliance on the 'field of dreams' myth at this site, and potentially other restoration myths (Hilderbrand et al., 2005), does not, in most instances, lead to a concomitant intensification in the recovery of soil microbial communities and their functional attributes. In fact, from a microbial perspective the act of agricultural cessation likely had the most marked influence on these soil communities, while efforts aimed at rapidly establishing trees had relatively little effect to date. Our results therefore help to validate the emerging use of practices which focus directly on restoring soil biotic communities and their functions, through restoration treatments such as transplanting a thin layer of topsoil - albeit labor intensive - from sites similar to the restoration end-point (Kardol et al., 2009; Pywell et al., 2011; Vecrin and Muller, 2003; Wubs et al., 2016). That is, building a better aboveground community does not ensure that an equivalent belowground community will take the field, and so the focus should be on directly establishing both the aboveground and belowground players in future restoration efforts rather than relying on restoration myths (sensu Hilderbrand et al., 2005).

\section{Acknowledgements}

We thank Stephen Wood and Evelyn Wenk for field assistance. This project was funded through a cooperative agreement between USFS
Southern Research Station and Yale University.

\section{Appendix A. Supplementary data}

Supplementary data associated with this article can be found, in the online version, at http://dx.doi.org/10.1016/j.apsoil.2017.07.008.

\section{References}

Abarenkov, K., Nilsson, R.H., Larsson, K.-H., Alexander, I.J., Eberhardt, U., Erland, S., Hoiland, K., Kjoller, R., Larsson, E., Pennanen, T., Sen, R., Taylor, A.F.S., Tedersoo, L. Ursing, B.M., Vralstad, T., Liimatainen, K., Peintner, U., Koljalg, U., 2010. The UNITE database for molecular identification of fungi - recent updates and future perspectives. New Phytol. 186, 281-285.

Anderson, M., Gorley, R., Clarke, K., 2008. PerMANOVA + for Primer: Guide to Software and Statistical Methods. Primer-E Ltd, Plymouth, United Kingdom.

Averill, C., Hawkes, C.V., 2016. Ectomycorrhizal fungi slow soil carbon cycling. Ecol. Lett. 19, 937-947.

Brewer, T.E., Handley, K.M., Carini, P., Gilbert, J.A., Fierer, N., 2016. Genome reduction in an abundant and ubiquitous soil bacterium 'Candidatus Udaeobacter copiosus'. Nat. Microbiol. 2, 1-7. http://dx.doi.org/10.1038/nmicrobiol.2016.198.

Buckley, D.H., Schmidt, T.M., 2001. Environmental factors influencing the distribution of rRNA from Verrucomicrobia in soil. FEMS Microbiol. Ecol. 35, 105-112.

Burns, R., DeForest, J., Marxsen, J., Sinsabaugh, R., Stromberger, M., Wallenstein, M.D. Weintraub, M.N., Zoppini, A., 2013. Soil enzymes in a changing environment: current knowledge and future directions. Soil Biol. Biochem. 58, 216-234.

Callaham, M.A., Rhoades, C.C., Heneghan, L., 2008. A striking profile: soil ecological knowledge in restoration management and science. Restor. Ecol. 16, 604-607.

Caporaso, J.G., Lauber, C.L., Walters, W.A., Berg-Lyons, D., Lozupone, C.A., Turnbaugh, P.J., Fierer, N., Knight, R., 2011. Global patterns of 16S rRNA diversity at a depth of millions of sequences per sample. Proc. Natl. Acad. Sci. U. S. A. 108, 4516-4522.

Chazdon, R.L., 2008. Beyond deforestation: restoring forests and ecosystem services on degraded lands. Science 320, 1458-1460.

Clarke, K., Gorley, R., 2006. PRIMER v6: User Manual/Tutorial. PRIMER-E, Plymouth.

Clarke, K.R., 1993. Nonparametric multivariate analyses of changes in community structure. Aust. J. Ecol. 18, 117-143.

Cotrufo, M.F., Wallenstein, M.D., Boot, C.M., Denef, K., Paul, E., 2013. The Microbial Efficiency-Matrix Stabilization (MEMS) framework integrates plant litter decomposition with soil organic matter stabilization: do labile plant inputs form stable soil organic matter? Glob. Change Biol. 19, 988-995.

de Graaff, M.A., Classen, A.T., Castro, H.F., Schadt, C.W., 2010. Labile soil carbon inputs mediate the soil microbial community composition and plant residue decomposition rates. New Phytol. 188, 1055-1064.

De Steven, D., Faulkner, S.P., Keeland, B.D., Baldwin, M.J., McCoy, J.W., Hughes, S.C., 2015. Understory vegetation as an indicator for floodplain forest restoration in the Mississippi River Alluvial Valley, USA. Restor. Ecol. 23, 402-412.

DeForest, J.L., 2009. The influence of time, storage temperature, and substrate age on potential soil enzyme activity in acidic forest soils using MUB-linked substrates and LDOPA. Soil Biol. Biochem. 41, 1180-1186.

Degens, B.P., Harris, J.A., 1997. Development of a physiological approach to measuring the catabolic diversity of soil microbial communities. Soil Biol. Biochem. 29, 1309-1320.

Duffy, D.C., Meier, A.J., 1992. Do appalachian herbaceous understories ever recover from clearcutting. Conserv. Biol. 6, 196-201.

Edgar, R.C., 2013. UPARSE: highly accurate OTU sequences from microbial amplicon reads. Nat. Methods 10, 996-998.

Eviner, V.T., Hawkes, C.V., 2008. Embracing variability in the application of plant-soil interactions to the restoration of communities and ecosystems. Restor. Ecol. 16, $713-729$.

Fierer, N., Strickland, M.S., Liptzin, D., Bradford, M.A., Cleveland, C.C., 2009. Global patterns in belowground communities. Ecol. Lett. 12, 1238-1249.

Fierer, N., Leff, J.W., Adams, B.J., Nielsen, U.N., Bates, S.T., Lauber, C.L., Owens, S. Gilbert, J.A., Wall, D.H., Caporaso, J.G., 2012. Cross-biome metagenomic analyses of soil microbial communities and their functional attributes. Proc. Natl. Acad. Sci. U. S. A. 109, 21390-21395.

Fierer, N., Ladau, J., Clemente, J.C., Leff, J.W., Owens, S.M., Pollard, K.S., Knight, R., Gilbert, J.A., McCulley, R.L., 2013. Reconstructing the microbial diversity and function of pre-agricultural tallgrass prairie soils in the United States. Science 342, 621-624.

Foster, D., Swanson, F., Aber, J., Burke, I., Brokaw, N., Tilman, D., Knapp, A., 2003. The importance of land-use legacies to ecology and conservation. Bioscience 53, 77-88.

Gellie, N.J.C., Mills, J.G., Breed, M.F., Lowe, A.J., 2017. Revegetation rewilds the soil bacterial microbiome of an old field. Mol. Ecol. 2895-2904.

Grandy, A.S., Neff, J.C., 2008. Molecular C dynamics downstream: the biochemical decomposition sequence and its impact on soil organic matter structure and function. Sci. Total Environ. 404, 297-307.

Grandy, A.S., Strickland, M.S., Lauber, C.L., Bradford, M.A., Fierer, N., 2009. The influence of microbial communities, management, and soil texture on soil organic matter chemistry. Geoderma 150, 278-286.

Hamel, P.B., 2003. Winter bird community differences among methods of bottomland hardwood forest restoration: results after seven growing seasons. Forestry 76 , 189-197.

Harris, J., 2009. Soil microbial communities and restoration ecology: facilitators or 
followers? Science 325, 573-574.

Hilderbrand, R.H., Watts, A.C., Randle, A.M., 2005. The myths of restoration ecology. Ecol. Soc. 10, 19.

Holl, K.D., Aide, T.M., 2011. When and where to actively restore ecosystems? For. Ecol. Manage. 261, 1558-1563.

Hooker, T.D., Compton, J.E., 2003. Forest ecosystem carbon and nitrogen accumulation during the first century after agricultural abandonment. Ecol. Appl. 13, 299-313.

Houghton, R.A., Hackler, J.L., 2000. Changes in terrestrial carbon storage in the United States. 1: the roles of agriculture and forestry. Glob. Ecol. Biogeogr. 9, 125-144.

Hovatter, S.R., Dejelo, C., Case, A.L., Blackwood, C.B., 2011. Metacommunity organization of soil microorganisms depends on habitat defined by presence of Lobelia siphilitica plants. Ecology 92, 57-65.

Johnstone, J.F., Allen, C.D., Franklin, J.F., Frelich, L.E., Harvey, B.J., Higuera, P.E., Mack, M.C., Meentemeyer, R.K., Metz, M.R., Perry, G.L.W., Schoennagel, T., Turner, M.G., 2016. Changing disturbance regimes, ecological memory, and forest resilience. Front. Ecol. Environ. 14, 369-378.

Kardol, P., Wardle, D.A., 2010. How understanding aboveground-belowground linkages can assist restoration ecology. Trends Ecol. Evol. 25, 670-679.

Kardol, P., Bezemer, T.M., Van Der Putten, W.H., 2009. Soil organism and plant introductions in restoration of species-rich grassland communities. Restor. Ecol. 17, 258-269.

Keiser, A.D., Strickland, M.S., Fierer, N., Bradford, M.A., 2011. The effect of resource history on the functioning of soil microbial communities is maintained across time. Biogeosciences 8, 1477-1486.

Kulmatiski, A., Beard, K.H., 2011. Long-term plant growth legacies overwhelm short-term plant growth effects on soil microbial community structure. Soil Biol. Biochem. 43, 823-830.

Lauber, C.L., Strickland, M.S., Bradford, M.A., Fierer, N., 2008. The influence of soil properties on the structure of bacterial and fungal communities across land-use types. Soil Biol. Biochem. 40, 2407-2415.

Leff, J.W., Jones, S.E., Prober, S.M., Barberan, A., Borer, E.T., Firn, J.L., Harpole, W.S. Hobbie, S.E., Hofmockel, K.S., Knops, J.M.H., McCulley, R.L., La Pierre, K., Risch, A.C., Seabloom, E.W., Schutz, M., Steenbock, C., Stevens, C.J., Fierer, N., 2015. Consistent responses of soil microbial communities to elevated nutrient inputs in grasslands across the globe. Proc. Natl. Acad. Sci. U. S. A. 112, 10967-10972.

McDonald, D., Price, M.N., Goodrich, J., Nawrocki, E.P., DeSantis, T.Z., Probst, A., Andersen, G.L., Knight, R., Hugenholtz, P., 2012. An improved Greengenes taxonomy with explicit ranks for ecological and evolutionary analyses of bacteria and archaea. ISME J. 6, 610-618.

McGuire, K.L., Payne, S.G., Palmer, M.I., Gillikin, C.M., Keefe, D., Kim, S.J., Gedallovich, S.M., Discenza, J., Rangamannar, R., Koshner, J.A., Massmann, A.L., Orazi, G., Essene, A., Leff, J.W., Fierer, N., 2013. Digging the New York city skyline: soil fungal communities in green roofs and city parks. PLoS One 8, e58020.

Nguyen, N.H., Song, Z.W., Bates, S.T., Branco, S., Tedersoo, L., Menke, J., Schilling, J.S., Kennedy, P.G., 2016. FUNGuild: an open annotation tool for parsing fungal community datasets by ecological guild. Fungal Ecol. 20, 241-248.

Ohsowski, B.M., Klironomos, J.N., Dunfield, K.E., Hart, M.M., 2012. The potential of soil amendments for restoring severely disturbed grasslands. Appl. Soil Ecol. 60, 77-83.

Phillips, R.P., Brzostek, E., Midgley, M.G., 2013. The mycorrhizal-associated nutrient economy: a new framework for predicting carbon-nutrient couplings in temperate forests. New Phytol. 199, 41-51.

Prober, S.M., Leff, J.W., Bates, S.T., Borer, E.T., Firn, J., Harpole, W.S., Lind, E.M., Seabloom, E.W., Adler, P.B., Bakker, J.D., Cleland, E.E., DeCrappeo, N.M. DeLorenze, E., Hagenah, N., Hautier, Y., Hofmockel, K.S., Kirkman, K.P., Knops, J.M.H., La Pierre, K.J., MacDougall, A.S., McCulley, R.L., Mitchell, C.E., Risch, A.C., Schuetz, M., Stevens, C.J., Williams, R.J., Fierer, N., 2015. Plant diversity predicts beta but not alpha diversity of soil microbes across grasslands worldwide. Ecol. Lett. 18, 85-95.

Pywell, R.F., Meek, W.R., Webb, N.R., Putwain, P.D., Bullock, J.M., 2011. Long-term heathland restoration on former grassland: the results of a 17-year experiment. Biol. Conserv. 144, 1602-1609.

R Core Team, 2012. R: A Language and Environment for Statistical Computing. R Foundation for Statistical Computing, Vienna, Austria.

Schmidt, M.W.I., Torn, M.S., Abiven, S., Dittmar, T., Guggenberger, G., Janssens, I.A., Kleber, M., Kogel-Knabner, I., Lehmann, J., Manning, D.A.C., Nannipieri, P., Rasse, D.P., Weiner, S., Trumbore, S.E., 2011. Persistence of soil organic matter as an ecosystem property. Nature 478, 49-56.

Sinsabaugh, R.L., Lauber, C.L., Weintraub, M.N., Ahmed, B., Allison, S.D., Crenshaw, C., Contosta, A.R., Cusack, D., Frey, S., Gallo, M.E., Gartner, T.B., Hobbie, S.E., Holland, K., Keeler, B.L., Powers, J.S., Stursova, M., Takacs-Vesbach, C., Waldrop, M.P., Wallenstein, M.D., Zak, D.R., Zeglin, L.H., 2008. Stoichiometry of soil enzyme activity at global scale. Ecol. Lett. 11, 1252-1264.

Stanturf, J.A., Gardiner, E.S., Hamel, P.B., Devall, M.S., Leininger, T.D., Warren, M.E. 2000. Restoring bottomland hardwood ecosystems in the Lower Mississippi Alluvial Valley. J. For. 98, 10-16.

Stanturf, J.A., Gardiner, E.S., Shepard, J.P., Schweitzer, C.J., Portwood, C.J., Dorris, L.C. 2009. Restoration of bottomland hardwood forests across a treatment intensity gradient. For. Ecol. Manage. 257, 1803-1814.

Stanturf, J.A., Palik, B.J., Dumroese, R.K., 2014. Contemporary forest restoration: a review emphasizing function. For. Ecol. Manage. 331, 292-323.

Strickland, M.S., Lauber, C., Fierer, N., Bradford, M.A., 2009. Testing the functional significance of microbial community composition. Ecology 90, 441-451.

Strickland, M.S., Callaham, M.A., Davies, C.A., Lauber, C.L., Ramirez, K., Richter, D.D., Fierer, N., Bradford, M.A., 2010a. Rates of in situ carbon mineralization in relation to land-use, microbial community and edaphic characteristics. Soil Biol. Biochem. 42, 260-269.

Strickland, M.S., Devore, J.L., Maerz, J.C., Bradford, M.A., 2010b. Grass invasion of a hardwood forest is associated with declines in belowground carbon pools. Glob. Change Biol. 16, 1338-1350.

Strickland, M.S., McCulley, R.L., Nelson, J.A., Bradford, M.A., 2015. Compositional differences in simulated root exudates elicit a limited functional and compositional response in soil microbial communities. Front. Microbiol. 6, 1-9. http://dx.doi.org/ 10.3389/fmicb.2015.00817.

Suding, K., Higgs, E., Palmer, M., Callicott, J.B., Anderson, C.B., Baker, M., Gutrich, J.J., Hondula, K.L., LaFevor, M.C., Larson, B.M.H., Randall, A., Ruhl, J.B., Schwartz, K.Z.S., 2015. Committing to ecological restoration. Science 348, 638-640.

Tedersoo, L., Bahram, M., Polme, S., Koljalg, U., Yorou, N.S., Wijesundera, R., Ruiz, L.V., Vasco-Palacios, A.M., Thu, P.Q., Suija, A., Smith, M.E., Sharp, C., Saluveer, E., Saitta, A., Rosas, M., Riit, T., Ratkowsky, D., Pritsch, K., Poldmaa, K., Piepenbring, M., Phosri, C., Peterson, M., Parts, K., Partel, K., Otsing, E., Nouhra, E., Njouonkou, A.L., Nilsson, R.H., Morgado, L.N., Mayor, J., May, T.W., Majuakim, L., Lodge, D.J., Lee, S.S., Larsson, K.H., Kohout, P., Hosaka, K., Hiiesalu, I., Henkel, T.W., Harend, H., Guo, L.D., Greslebin, A., Grelet, G., Geml, J., Gates, G., Dunstan, W., Dunk, C., Drenkhan, R., Dearnaley, J., De Kesel, A., Dang, T., Chen, X., Buegger, F., Brearley, F.Q., Bonito, G., Anslan, S., Abell, S., Abarenkov, K., 2014. Global diversity and geography of soil fungi. Science 346, 1078-1088.

Theobald, D.M., 2010. Estimating natural landscape changes from 1992 to 2030 in the conterminous US. Landsc. Ecol. 25, 999-1011.

van der Putten, W.H., Bardgett, R.D., Bever, J.D., Bezemer, T.M., Casper, B.B., Fukami, T., Kardol, P., Klironomos, J.N., Kulmatiski, A., Schweitzer, J.A., Suding, K.N., Van de Voorde, T.F.J., Wardle, D.A., 2013. Plant-soil feedbacks: the past, the present and future challenges. J. Ecol. 101, 265-276.

Vecrin, M.P., Muller, S., 2003. Top-soil translocation as a technique in the re-creation of species-rich meadows. Appl. Veg. Sci. 6, 271-278.

Wall, D.H., Nielsen, U.N., Six, J., 2015. Soil biodiversity and human health. Nature 528, 69-76.

Wang, Q., Garrity, G.M., Tiedje, J.M., Cole, J.R., 2007. Naive Bayesian classifier for rapid assignment of rRNA sequences into the new bacterial taxonomy. Appl. Environ. Microbiol. 73, 5261-5267.

Wardle, D.A., Bardgett, R.D., Klironomos, J.N., Setala, H., van der Putten, W.H., Wall, D.H., 2004. Ecological linkages between aboveground and belowground biota. Science 304, 1629-1633.

White, T.J., Bruns, T., Lee, S., Taylor, J., 1990. Amplification and direct sequencing of fungal ribosomal RNA genes for phylogenetics. In: Innis, M.A., Gelfand, D.H., Sninsky, J.J., White, T.J. (Eds.), PCR Protocols: A Guide to Methods and Applications. Academic Press, Inc, San Diego, CA USA, pp. 315-322.

Wubs, E.R.J., van der Putten, W.H., Bosch, M., Bezemer, T.M., 2016. Soil inoculation steers restoration of terrestrial ecosystems. Nat. Plants 2, 1-5. http://dx.doi.org/10 1038/nplants.2016.107.

Zhang, N., Wang, Z., 2015. Pezizomycotina: sordariomycetes and leotiomycetes. In: McLaughlin, D., Spatafora, J. (Eds.), The Mycota VII Systematics and Evolution Part B. Springer-Verlag, Berlin, Heidelberg, pp. 57-88. 